\title{
A Techno-Economic Assessment of the Design and Operation of a Windfarm in Europe

\author{
K R Prajwal
}

\begin{abstract}
Offshore wind farm is a matured technology in renewable energy with continuous improvement over the years in-terms of technology. The resources are stronger and abundant compared to the land-based wind resources leading to higher wind energy capture and conversion. This paper highlights the development of offshore wind projects in Europe while addressing the design, challenges associated with the structure, maintenance, costing and decommissioning. To make the offshore farm construction and maintenance feasible coupled with reliability, different aspect of logistics and supply chain management are also reviewed in this paper.

Keywords: wind turbine, transmission, marinization, capacity factor, installation, foundation, logistics
\end{abstract}

\section{INTRODUCTION}

The diminution of economic reliance on energy from fossil fuels is the main concern of the various governments around the world. The existing reserves of fossil fuel are limited and also have a significant adverse impact on the atmosphere by raising the carbon level and contribute to global warming. Presently, the Renewable energy sources like wind, solar and hydro are currently contributing about fifty percent of the world's energy demand [1]. Among the renewable energy sources, offshore wind energy is one of the most promising and growing technology during the last decade.

Table- I:Operational offshore wind farms in the EU [6]

\begin{tabular}{|c|c|c|c|c|c|c|c|}
\hline No & Project, location & Capacity (MW) & $\begin{array}{l}\text { Number of } \\
\text { rurtines }\end{array}$ & $\begin{array}{l}\text { Water } \\
\text { depth (m) }\end{array}$ & $\begin{array}{l}\text { Distance to } \\
\text { shore (km) }\end{array}$ & $\begin{array}{l}\text { Vear of } \\
\text { installation }\end{array}$ & $\begin{array}{l}\text { Wind rurbine } \\
\text { mamufacturer }\end{array}$ \\
\hline 1 & Vindeby, Denmark & 4.95 & 11 & $2.5-5$ & 2.5 & 1991 & Bonแs \\
\hline 2 & Lely, Netheriands & 2 & 4 & 7.5 & 0.75 & 19924 & Nedwind \\
\hline 3 & Tune Knob, Denmark & 5 & 10 & $0.8-4$ & 6 & 1995 & Vestas \\
\hline 4 & trene Vorrink, Nethertands & 16.8 & 28 . & 2 & 0.03 & 1996 & Nordrank \\
\hline 5 & Bockstigen, Sweden & 2.8 & 5 & $6-8$ & 3 & 19008 & Winworld \\
\hline 6 & Blyth, United Kingdom & 3.8 & 2 & & $i$ & 2000 & Vestas \\
\hline ; & Middeigrunden. Denmark & 40 & 20 & $5-10$ & $2-3$ & 2001 & nonus \\
\hline 8 & $\begin{array}{l}\text { Utgrunden L, Sweden } \\
\text {. }\end{array}$ & 105 & 7 & $4=10$ & 7 & 2001 & $G E$ \\
\hline 9 & Horns Rev 1, Denmark & 100 & 80 & 6-14 & $14-17$ & 2002 & Vestas \\
\hline 10 & Vttre Stengnund, sweden & 10 & 5 & $n-12$ & & 2002 & NitG-Micon \\
\hline "1 & Nysted, Denmark & 105.6 & 72. & $6-10$ & $0-10$ & 2003 & Siemens \\
\hline 12 & Samse, Denmark & 23 & 10 & $11-18$ & is & 2003 & nonus \\
\hline 13 & Frederikshavn, Denmark & 10.6 & 4 & 3 & 0.8 & 2003 & Vestas, Bonus, Nordex \\
\hline 14 & North Hoyle, United Kangdom & 60 & 30 & $5-12$ & 7.5 & 2003 & Vestas \\
\hline 15 & EndenEms, Germany & 45 & 1 & $=$ & $\& 1$ & 2004 & Enercon \\
\hline 16 & Arklow Bank, treland & 25.2 & 7 & 15 & 10 & 2004 & GE \\
\hline 17 & Scroby Sands, United Kingdem & 60 & 30 & $2-10$ & 3 & 2004 & vestas \\
\hline in & Kentish Aats, United Kingdom & 90 & 30 & 5 & is.s & 2005 & Vestas \\
\hline is & Breiting. Cermany & 2.3 & 1 & 2 & & 2006 & Nordex \\
\hline 20 & Egmong ann Zec, Nethertands & $10 \mathrm{~A}$ & 36 & $17-23$ & $=12$ & 2006 & vestas \\
\hline 21 & Barrow, United Kingdom & 90 & 30 & is & 7 & 2006 & Vestas \\
\hline$n$ & Lillgrund, Sweden & 110 & 48 & $2.5-9$ & 10 & 2007 & siemens \\
\hline 23 & Beatrice. United Kingdom & 10 & 2 & 40 & 25 & 2007 & Repower \\
\hline 24 & Burbo Bank, United Kingdom & no & 25 & 10 & 5.2 & 2007 & siemens \\
\hline 25 & Thornton asnk phase 1 , Beigium & 30 & 6 & $12-27$ & $27-30$ & 2008 & Bepower \\
\hline 26 & Kemi fjos phases I, 2 , finland & 24 & " & - & $\approx 1$ & 20011 & \\
\hline 27 & Hookaiel, Germany & & 1 & $2-\|$ & 0.4 & $200 \mathrm{~B}$ & Enercon \\
\hline $2 n$ & Birindisi, Italy & o.om & 1 & 108 & 20 & 20011 & Hlue II \\
\hline 20 & Prinses Amalia. Netherlands & 120 & 60 & $10-24$ & 23 & 2008 & Vestas \\
\hline \multirow{3}{*}{$\begin{array}{l}30 \\
31\end{array}$} & Inner Dowsing. United Kingdom & 90 & 30 & 10 & 5.2 & 2008 & Siemens \\
\hline & Lynn, United Kingdom & 97 & 30 & 10 & 5.2 & 2008 & siemens \\
\hline & Total & 1471.33 & & & & & \\
\hline
\end{tabular}

A wind energy system transforms the kinetic energy of the wind to electrical energy [2].It is one of the cheapest forms of renewable energy, environmentally friendly, carbon neutral form of energy. The environmental impacts of wind turbines are negligible when compared to conventional energy sources derived from fossil fuels [3]. The significant advantages foroffshore installations include high averagewind speed, hencesignificantly improving the capacity factor and generating more energy. Also, deeper water has less surface roughness than land. A country's territorial waters extends up to 12 nautical miles from its baseline which can be further extended to 200 nautical miles from coastline under Exclusive Economic Zone [4].

Revised Manuscript Received on January 03, 2020.

* Correspondence Author

K R Prajwal*, School of Biological and Marine Sciences, University of Plymouth, Plymouth, United Kingdom. Email: prajwal4491@gmail.com

(c) The Authors. Published by Blue Eyes Intelligence Engineering and Sciences Publication (BEIESP). This is an open access article under the CC BY-NC-ND license (http://creativecommons.org/licenses/by-nc-nd/4.0/)
The offshore wind farm can be developed anywhere under those limits considering other factors with respect to development like installation, operational feasibility, logistics, maintenance and costs.

The offshore development commenced in the year 1991with Denmark building a $4.95 \mathrm{MW}$ windfarm at Vindeby located $2.5 \mathrm{~km}$ offshore. The water depths at the site was about $5 \mathrm{~m}$ and it generated $12 \mathrm{GWh} /$ year [5].The development of offshore windfarms between the year 1991 and 2008 is given in figure 1 [6]. The operational windfarms are given in table 1 [6].In this paper, different aspects of the challenges facing the offshore wind industry is discussed with reference to the relative costs of design, manufacture, installation and operation of offshore wind turbine.

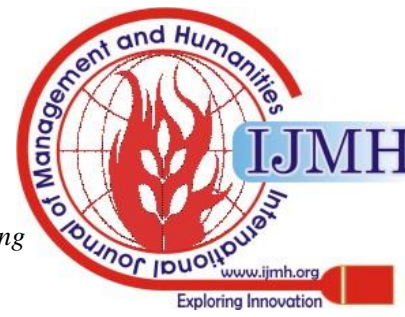




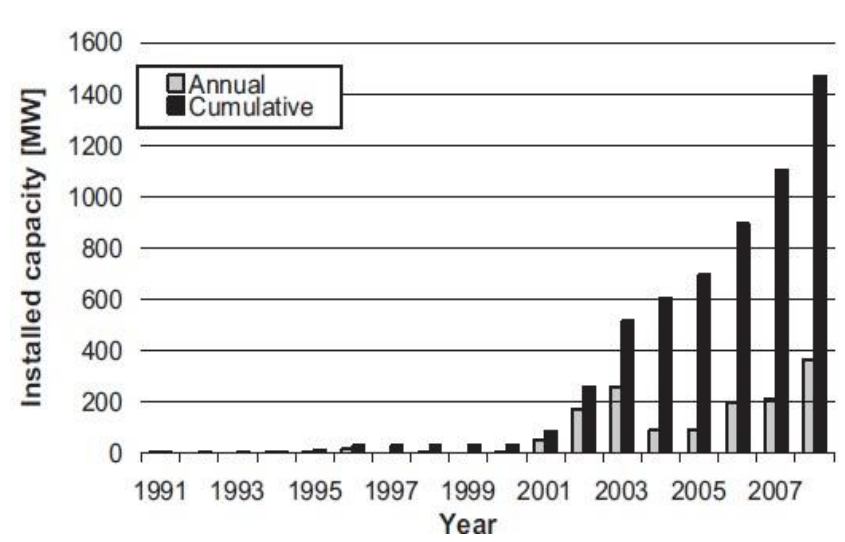

Fig. 1.Development of offshore wind power in EU from 1991-2008 [6]

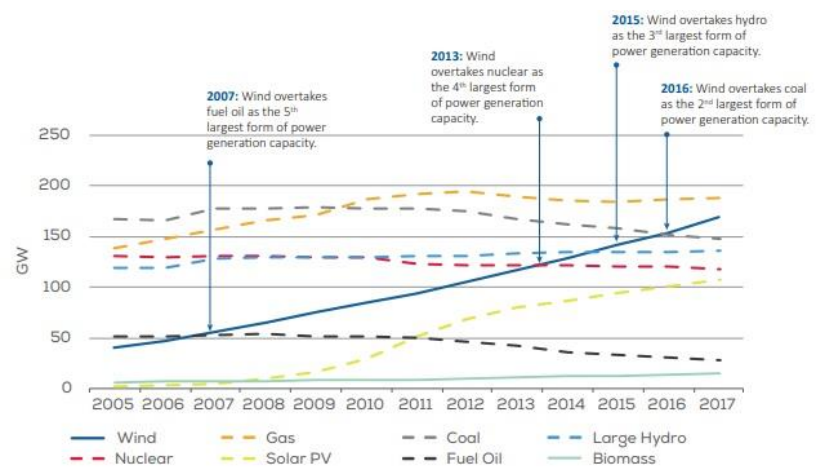

Fig. 2.Power generation capacity in EU from 20052017[7]

\section{CURRENT STATUS}

Wind energy is the world's fastest growing energy alongside solar energy. European Union is rapidly adding wind power to its generating capacity compared to other sources of energy as seen from figure 2 [7]. The UK overtook Denmark in the year 2008 for the largest installed capacity for offshore wind. EU installed 15.6 GW of wind power capacity in 2017 with total capacity of $168.7 \mathrm{GW}$ with $12.4 \mathrm{GW}$ onshore and $3.4 \mathrm{GW}$ offshore capacity [7]. Figure 3 shows the installed wind energy capacity in the EU during 2017 [7]. Most of the offshore wind farms were installed in relatively shallow waters but with the technology improving, the windfarms are now moving to deeper waters. It can be seen from Figure 4 the steady rate of increase in offshore wind energy installations over the years as companies tend to develop bigger and better turbines for generating power offshore [7].

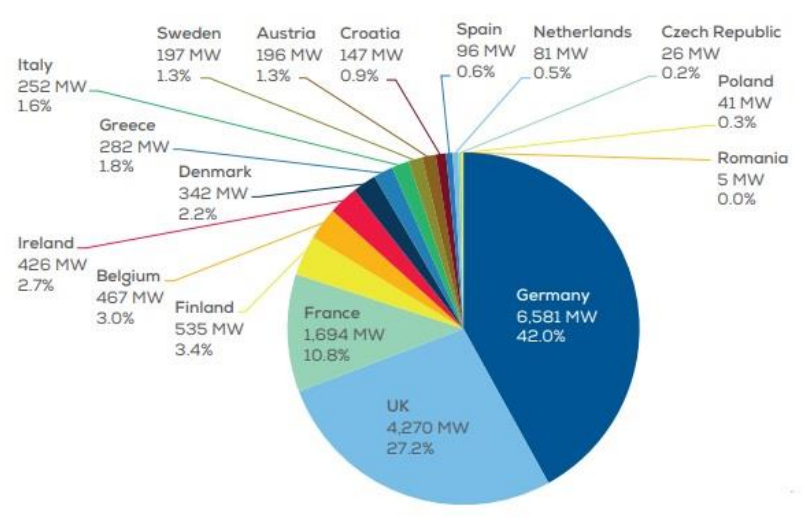

Fig. 3.Installed wind capacity in EU during 2017 [7]

Retrieval Number: E0494014520/2020@BEIESP

DOI:10.35940/ijmh.E0494.014520

Journal Website: www.ijmh.org

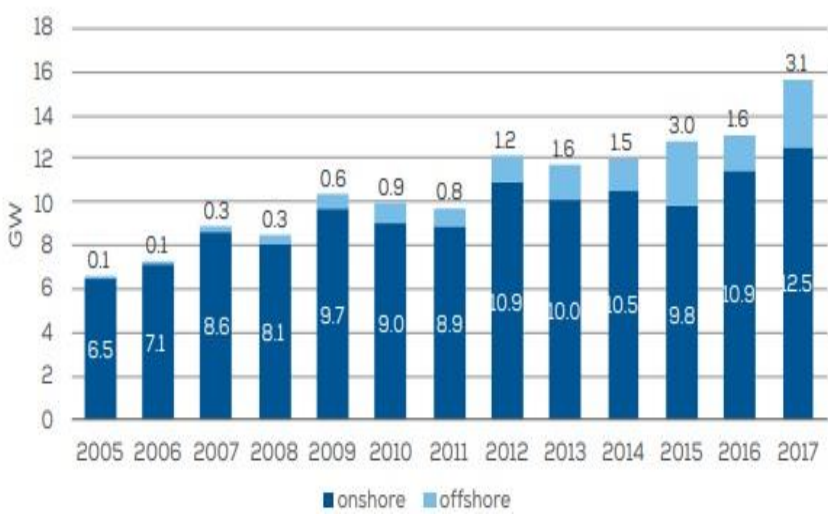

Fig. 3.Installed offshore and onshore wind capacity in EU[7]

\section{TURBINE DESIGN AND GRID CONNECTION}

\section{A. Components of wind turbine}

The offshore wind turbine is made of different components. The components include the foundation and a support structure to support the entire structure. The transition piece, tower, the rotor blades and the nacelle are all mounted on the support structure. The tower is made of steel and the nacelle contains the turbine and generator with the gearbox. The tower also consists a transformer to step-up the generated power [8]. The blowing wind causes the rotor blades to rotate which drives the shaft connected to the gearbox which is connected to the generator. The taller the turbines and the size of the blades, the generated energy is more as wind speed is much higher at the higher altitudes. As the rotor blades get longer, the total area increases by pi radius squared. So, if the rotor length is doubled, the swept area would have increased by four times, leading to larger capture width [8].

\section{B. Wind Farm Layout}

The wind farm layout has to be designed carefully to enable optimum energy conversion. The wind turbines are usually spaced laterally 4 to 8 times the rotor diameter to minimize wake effect [8]. Improper spacing of the turbines may lead to turbulence which results in the drop of capacity factor after the first row of turbines. Also, the layout has to be designed to minimize the amount of cabling required to keep the overall costs low. The layout of the wind farm is shown in figure 4 [9].

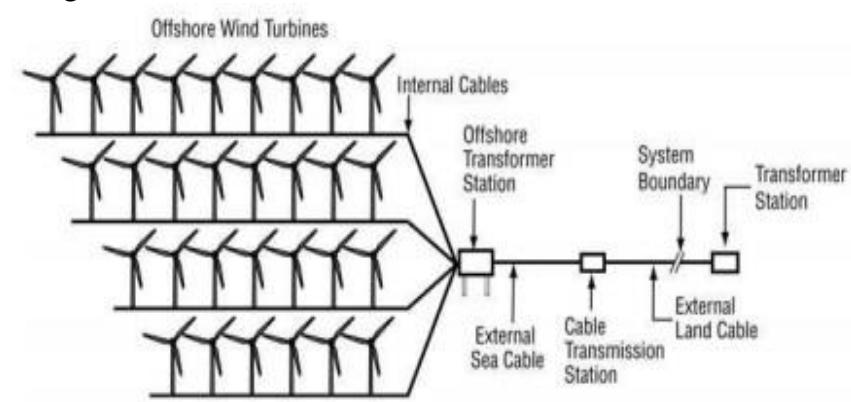

Fig. 4.Wind farm layout [9]

Published By:

Blue Eyes Intelligence Engineering

\& Sciences Publication

(C) Copyriaht: All rights reserved.

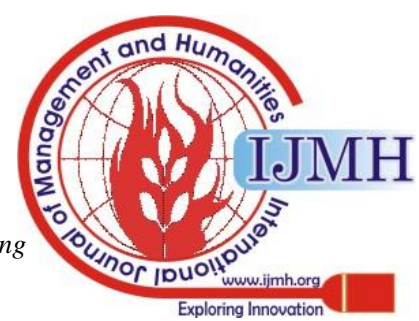




\section{Wind energy conversion systems}

The turbine is the most important component for wind power generation as it determines the efficiency of generation and also determines the profit for the developer in-terms of seeling the generated power and also determines the O\&Mcosts. Continuous research and development have led to increase in the rotor diameter and the overall power rating of the wind turbine.Different types of generators like Double Fed Induction Generator(DFIG), Squirrel Cage Induction Generator(SCIG) and Synchronous Permanent Magnet Generator (SPMG) are used for power generation.

- DFIG: This type of generator contains a set of slip rings and the rotor is powered by an AC/DC converter with frequency control. The rotor speed can vary over a wide range and the size of the electronic control is small. The injected power control is similar to synchronous generators and is usually efficient in power conversion. However, this generator requires frequent maintenance due to the presence of slip rings.

- SCIG: This type of generator is made of aluminium rings which are connected to copper bars electrically. The generator is very robust, highly flexible in operation and smaller in size. However, the need of large capacitor banks to provide reactive power for the magnetization of the rotor is considered a major disadvantage.

- SPMG:This type of generators completely rules out the use of gearbox thereby reducing a major portion of cost and weight in the development of turbine. The design incorporates high number of poles to control the speed of the rotor. The design also incorporates high performance converters for control [10].

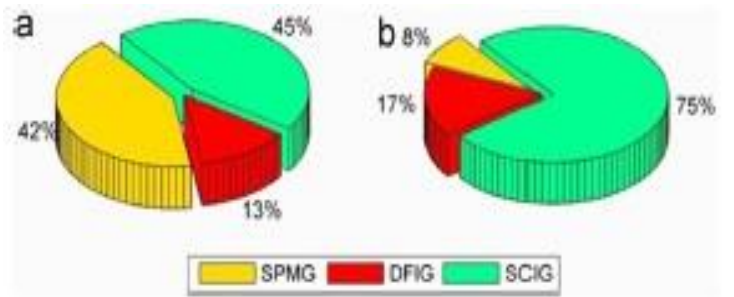

Fig. 4.Types of generators installed in Europe. (a) Overall windfarms. (b) Installation between 2013-2015 [11]

From figure 4[11], it can be seen that developers tend to use SPMG and SCIG more compared to DFIG. However, for the windfarms commissioned between 2013-2015, SCIG is way ahead in-terms of installation compared to other generators. Therefore, SCIG is best suited for use in marine applications compared to DFIG, which requires periodic maintenance due to replacement of rings thereby impacting the maintenance costs. Also, the stator needs to be connected to the grid for operation and this may lead to probability of a failure in the generator. Also, since the costs of SPMG are very high at the moment, it discourages the developers to use it [12].

\section{Transmission}

The transmission of the power generated has to be efficiently be transported to the onshore substation for the distribution of power. The transmission is done by a set of subsea cables and the power is either transmitted by using
HVAC or HVDC transmission systems. The generated power is collected offshore and the power is stepped up to a desired high voltage of $11 / 33 / 66 \mathrm{kV}$ based on the requirements using a step-up transformer on-board the offshore platform and transmitted. For HVDC, there is an extra converter located with the transformer for power conversion from AC to DC. The advantage of HVDC conversion is it is cheaper to transmit over long distances especially considering the fact that the windfarms are moving further offshore and it also highly efficient as losses are less compared to HVAC transmission [11].

\section{E. Marinization}

The Marinization component covers special preparation for all the components of the offshore structure. It is basically required for the components of wind turbine to endure harsh operating environment of the deep seas. They include special anti-corrosive paints and coatings for the structure, proper sealing and insulation for generator and other electrical components and connections. Marinization is calculated on the basis of the infrastructure costs. It is usually calculated to be $13.5 \%$ of the tower and turbine costs [13].

\section{F. Performance}

The performance of the offshore wind turbine is calculated on the basis of capacity factor. Capacity factor is defined as the ratio of average power generated by the rated peak power of the turbine over a period of 1 year [14]. The number 8760 is the number of hours in a year.

\section{Capacity Factor $=\underline{\text { Annual Energy Production }} * 100 \%$ Rated Power * 8760}

The size of the turbine also affects the performance of the turbine. If the size of the turbine is large with bigger blades and rotors to potentially cover a wide area, then the production increases. The blades should be placed higher in the atmosphere, where the wind is steadier and more predictable. This leads to increase in the capacity factor of the turbine. Due to technological advancements, the capacity factor for offshore wind farms have steadily increased from $25.4 \%$ in early 2000 's to $42.5 \%$ in $2014-2015$ [15]

\section{FOUNDATIONS}

Offshore turbines can be mounted on supporting structures which are ably supported by a foundation that extends from sea bed to sea level to support the tower sitting on top of it. The commonly used foundations are gravity-based foundations, piled foundations and skirt/bucket foundations, moored floating foundations [16]. The support structures can be categorised as monopile, tripod, lattice, gravity and floating structures.

- Gravity Based: This type of foundation is a is a buoyant structure with a series of cells that form the base. The base is anchored to the foundation made of sand, rock, concrete.

Published By:

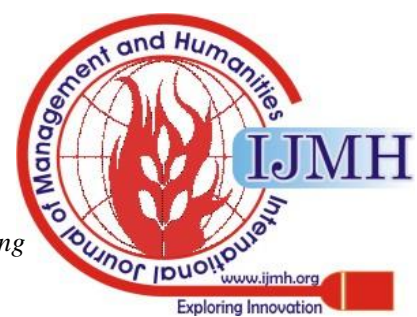


This type is suited when the depth is low and there are cost constraints on hiring heavy lift vessels for installation. There is sufficient amount of dead load provided at the bottom of the sea bed for the structure to maintain stability in all conditions.

- Piled foundations:Piled foundations are one of the most widely used structures in offshore industry. These are installed when the water depth is more than $50 \mathrm{~m}$. The piled foundations like monopile, tripod, lattice is usually fabricated on the vessels or on the shore and lifted to the site using heavy lifting vessels and are then driven into the seabed using hydraulic powered hammers.

- Skirt/bucket foundations: The suction bucket steel structure consists of a centre column connected to a steel bucket through flange-reinforced shear panels, which distribute the loads from the centre column to the edge of the bucket. The wind turbine tower is connected to the centre tubular above sea level. The steel bucket consists of vertical steel skirts extending down from a horizontal base resting on the seabed. The bucket then acts as gravity foundation, relying on the weight of the soil encompassed by the steel bucket. It is suited for water depths up to $30 \mathrm{~m}$.

- Moored floating foundations: This type of structure takes support from the mooring chains and anchors fixed to the seabed. The structure can be towed to the site and floaters can be connected to the anchors. The anchors can be fluke anchors, suction anchors, plate anchors based on the sea conditions. A stabiliser is placed at the bottom of the floater to provide stability to the structure. This type of structure is used in large water depths [17]

The different types of structures with their permissible installation water depth are shown in figure 5 [9]

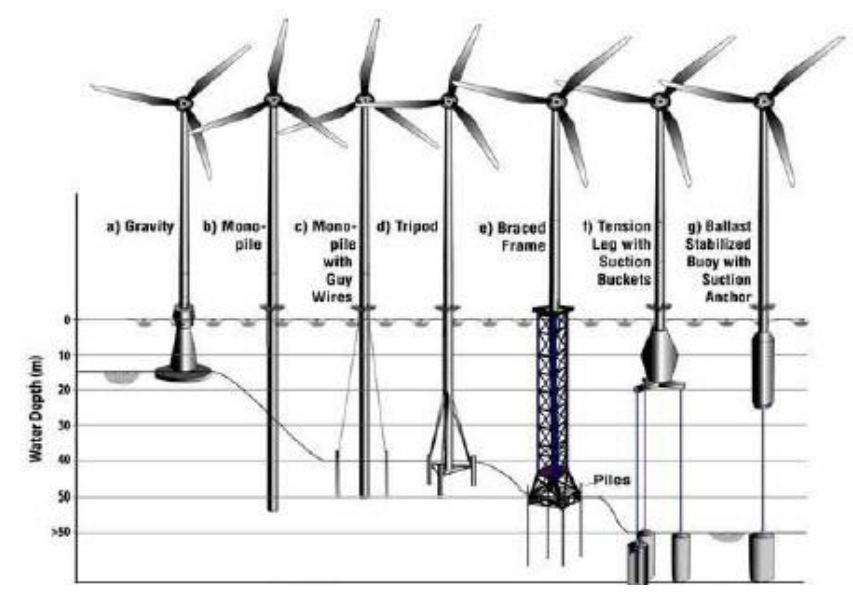

Fig. 5.Types of structures with their permissible water depth [9].

\section{STRUCTURAL CHALLENGES}

Offshore wind turbines are exposed to various structural challenges that can seriously degrade the performance and reduce the life cycle of the structures. Corrosion, fatigue damage, thermal stresses, wind loading, wave impacts and lightning strikes are of serious concern and can cause maximum damage to the structures. The foundation's structure can be divided into primary, secondary, tertiary steel structures based on their function. The primary steel structure has the main beams, trusses and all the connection joints and is important to support the entire structure. The secondary and tertiary structures are important but their failure doesn't threaten the structural integrity. All the components are exposed to harsh sea and environment. The structures must be designed to meet the operational requirements for 20-25 years without undergoing large scale repairs. The corrosion stress in an offshore wind structure is basically divided into four zones [18].

- Submerged zone where the structure is completely submerged. Generally cathodic protection and marinization is used for the protection in this zone.

- Tidal zone where the structure is exposed to air and water based on tidal cycles. The structure is exposed to chemical action, waves and other obstacles like ice and microorganisms. It is coated using special chemicals to prevent corrosion and routinely checked for failures.

- Splash zone where the structure is exposed to routine cycle of wetting and drying due to splashes of water. This type of structure is vulnerable to corrosion as salts are deposited on the surface after drying. They are coated using glass flake polymers to protect against mechanical damage.

- Atmospheric zone where the structure is exposed to the winds carrying salts. The structure is coated for protection.

Fatigue can occur due to the action of cyclic loading resulting in temporary or permanent damage to the structure. The main parameters influencing fatigue life are the material properties like welding defects, tensile strength, environmental effects like temperature and corrosion effects, geometrical properties like irregular shape, size and assembling errors and loading like tension, stress on the structure. The fatigue can be monitored and overcome by routine inspections and carrying out preventive maintenance on the structure [18].

\section{MANUFACTURING ASSEMBLY AND LOGISTICS}

Manufacturing components for offshore wind-farm installations involves a lot of vendors and supplies. All the components should be tested and certified before the final assembly. The developer should also be able to decide on the assembly, whether to do it onshore or offshore as it can have implications on the cost of the project. The manufacturing and sourcing of the components begins with the award of the contracts to the developer. Based on the size of the project and the availability of the vessels the developer can select a suitable site for the final assembly. The current status of blade technology includes a variety of designs and manufacturing processes. The blade manufacturer use epoxy for higher specific strength materials. For larger blades, carbon reinforcements are being used for the manufacturing.

Blue Eyes Intelligence Engineering

\& Sciences Publication

(C) Copyright: All rights reserved.

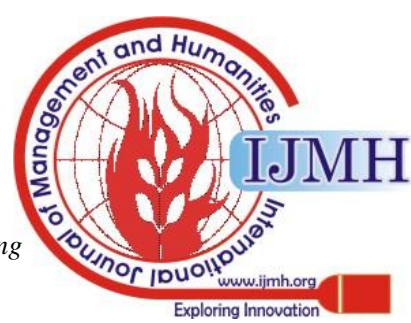


There is continuous development going on for tweaking the design of the blades for better efficiency but there's no radical development in the technology so far. The turbines are usually assembled in 7-8 parts based on size of the structure. For a $5 \mathrm{MW}$ turbine, the rotor diameter would be $122 \mathrm{~m}, 14 \mathrm{~m}$ long, $8.5 \mathrm{~m}$ wide and $8 \mathrm{~m}$ high nacelle is used. All the turbines today contain 3 blades [19].

The gearbox is one of the most important components in the wind turbine. The design of the gearbox is based on the input torque and the required speed increase ratio. The majority of the turbines have a gearbox working in the range of 1000 to $1500 \mathrm{rpm}$. Gearboxes are expensive and so developers are switching to direct drive technologies, which are cost effective and reliable compared to gearboxes

The future trends in manufacturing include increase in the percentage of carbon for manufacturing the blades and use of direct drive PMG systems [20].

Different assembly strategies are implemented depending on the size of the project. There are three main assembly methods widely followed are:

- Bunny Ear: Two blades of the turbine, nacelle and hub are assembled at the shore forming a design resembling a rabbit's head. The tower is carried in two pieces with the third blade.

- Full rotor star: In this type of assembly, hub and all the three blades are assembled at the shore. The Nacelle is assembled to the turbine offshore.

- Separate parts: The nacelle and the hub are assembled at the shore and the tower parts and the blades are carried separately to the site for assembly and installation [19].The logistics simply doesn't include transporting the components from the shore to the site but it's more of a streamlined process of planning, implementation and execution. The requirement for the logistics is based on the following factors:

- Size of the Windfarm: The size of the windfarm determines the number of vessels required for the transportation of the components and installation.

- Distance to the port: If the developer decides to assemble all his components on the shore, then the distance between the port and the site is an important factor to consider as the installation cost increases based on the distance from the site to the port.

The cost of the logistics has to be calculated thoroughly as the installation is usually dependent on the weather. Rough seas can lead to a delay in the installation and has direct implications on the cost. The renting of installation vessels can range from thousands of dollars to millions of dollars a daybased and hence any delay in the planned installation window might lead to huge increase in the costs of the project [19].

\section{OFFSHORE SUPPLY CHAIN MANAGEMENT}

The supply chain must be properly organised according to the timelines of the development. Any disturbance in the implementation may lead to increase in costs. The massive material requirements are needed in a short span of time mapped to a supply chain. All the stocks, inventory, production and delivery times must be synchronized with each other so that they are no hiccups in project delivery timeline.

The main challenge is the correct determination of the inventory stock in the port. The outgoing and incoming components must be maintained through a proper documentation. The supply chain process derived from the automobile industry is shown in figure 6 [21] with the probable disturbance variables. As can be seen from the figure above, the delay in production over the supply of the components can lead to the cascading effects on the overall manufacturing, logistics and implementation. The disturbances can reach over procurement problems to quality issues to traffic and weather conditions. In order to increase the streamlining of the process, a thorough planned time with a few reserve days need to be incorporated into every process [21].

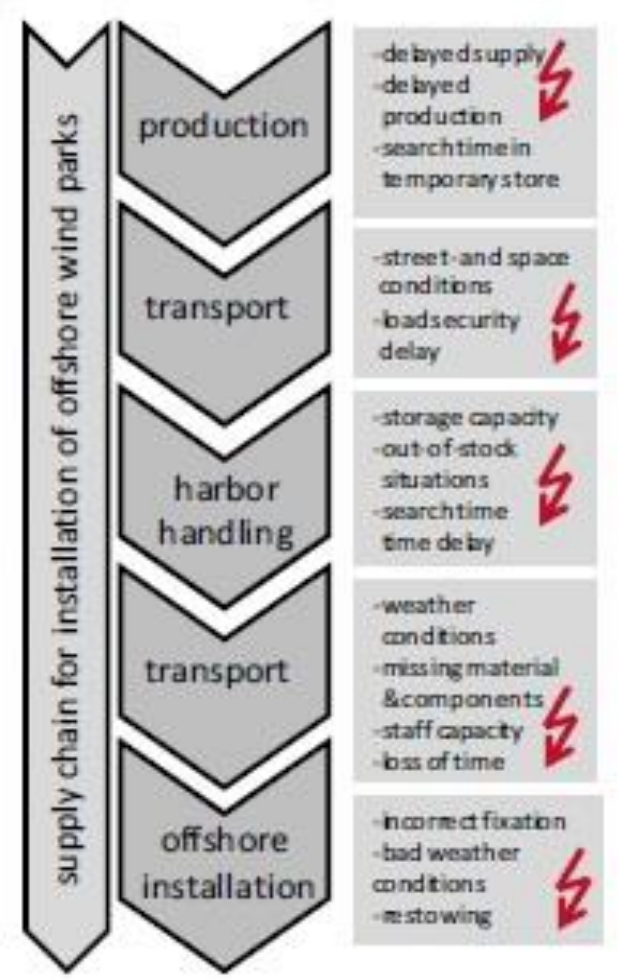

Fig. 6.Material flow process and its disturbance variables in the supply chain [21]

\section{INSTALLATION}

The installation of offshore wind farms can be extremely challenging because of extreme wind and wave conditions, heterogenous soil profiles. The foundation structures can be installed with greater airflow conditions but for the installation of tower, nacelle and blades requires calm sea conditions. There are three different type of installation scenarios as shown in figure 7 [22]. In figure 7a, the components are produced at location $\mathrm{M}$, then brought to a harbor $\mathrm{P}$ located on the shore. The components are assembled at harbor beforethey are then transported to the

Published By:

Blue Eyes Intelligence Engineering

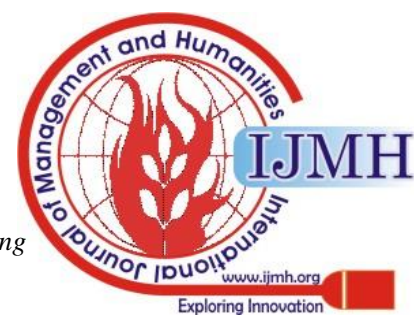

\& Sciences Publication

(c) Copyright: All rights reserved. 
site WF based on installation requirements. Since, the components are assembled at a land-based area, there is reduced risk of destruction to property in case of weather changes. In figure $7 \mathrm{~b}$, the components are manufactured at manufacturer's location $\mathrm{M}$ and transported directly to a location close to the site WF. The assembly usually is done on the construction vessels or offshore platforms which are usually smaller vessels compared to the larger installation vessels. In figure 7c, the manufacturedcomponents at location $\mathrm{M}$ are directly transported to the site WF using jack-up vessels. The jack-up vessels have lowered main pillars on the seabed to provide stability during installation process. These vessels can operate in medium water depths of up to $50 \mathrm{~m}$ and can operate at $50 \%$ more time than the other vessels [23].
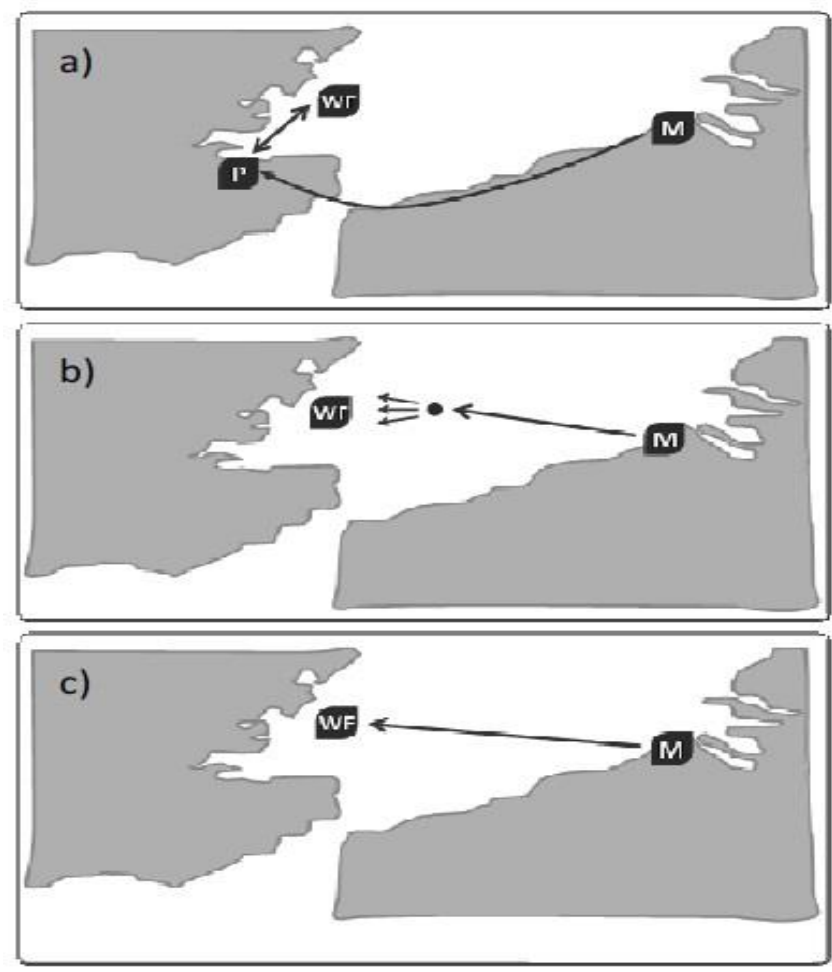

Fig. 7.Different installation scenarios [22]

Apart from the Jack-up vessels, there are several types of vessels like jackup barges, lift boats, self-propelled installation vessels (SPIVs). SPIVs are exclusively used for turbine installation. The primary requirements for the installation vessels are deck load, leg length and crane capacity.Lift boats have a range of 75 tons to 750 tons. SPIVs have variable deck loads of 1500 to 6500 tons.

The cable installation is the most vital part from installation. There are several methods in which this can be installed and they are discussed below [24].

- Simultaneous lay and bury: The plough is attached to a cable laying vessel and the cable is laid by a machine places on the vessel. The cable is buried in a trench of about $2 \mathrm{~m}$ deep which are dug by high pressure water jet. The water jet fluidizes sand or particles and the cable sinks inside the surface. This type of installation is widely used for laying export cables from the site to the shore.

- Simultaneous lay and bury using ROV: The method of installation is similar to the one described above but uses a ROV.
- Pre-excavate: This method is widely used for innerarray cable laying. Initially a trench is dug using a dredger and the cable is laid and the cable is then covered by the sludge or rocks using a dredger.

- Lay and trench: This method involves using both vessel and ROV for laying the cable. The cable is laid on the seabed with the help of cable laying machineand trenching the cable is done by ROV [24].

Export cables are the cables which connect offshore windfarm to the onshore substation. They can be either medium voltage (20-40 kV) or high voltage (above $110 \mathrm{kV}$ ) based on the requirements. They are usually installed by lay and bury method because of its weight and size.

The inner array cables are the cables which connect each WEC to a common offshore collection point. The cables are usually fed to the WEC with the help of divers and winch based on the structure used. This might lead to cost overrun as the operation is usually weather dependent. The burial depth is also influenced by soil type, scour and the government regulations [24].

\section{OPERATION AND MAINTENANCE}

As more offshore windfarms are being commissioned and the number of offshore turbines continue to grow in-terms of capacity, the finer technical details and challenges of operating projects is receiving more attention. Operations refers to day-to-day tasks like production, export, monitoring and other administrative tasks. The maintenance activity refers to the up-keep and repair of all the hardware equipment of the plant and continuous upgrade of the software systems. It can be categorised as preventive maintenance where maintenance or repair is done based on routine monitoring inspections and corrective maintenance where damaged parts are replaced. This type of maintenance is done with proper planning. The performance of a wind farm is measured on the basis of its availability to generate power throughout the year [25]. The most important factors in operation and maintenance are:

- Availability: It is measure of the performance of the windfarm.

- Scheduled and Unscheduled maintenance:The unscheduled maintenance is the one which takes place when a component fails. It might take a few hours to a couple of weeks depending on the type of failure. Scheduled maintenance is something that is usually planned well in advance to service the components of windfarm. This is usually done in summer months since wind speeds tend to be lower during summertime.

- Access:The major hurdle for maintaining offshore is getting engineers and service technicians on and off the turbines or offshore substations for carrying out maintenance work. The major factors affecting the approach taken to access are transit time and accessibility. The time taken for ferrying the engineers from the base to the site is called transit time.

Published By:

Blue Eyes Intelligence Engineering

\& Sciences Publication

(C) Copyriaht: All rights reserved.

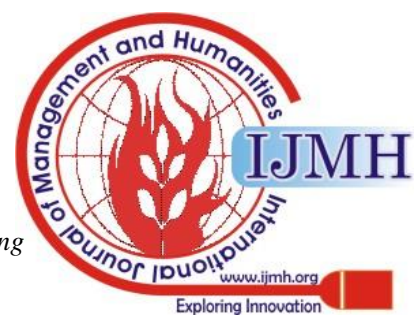


With limited time and risk of small fatigue developing into a major fault, it is important to have the main O\&M base near to the site. The technicians can be flown in choppers on ferried on boats to the site. Accessibility is the proportion of time a turbine can be safely accessed for maintenance for the crew. It is dependent on the weather conditions at the sea.

- Cost reduction:Reducing the cost of energy produced is the major focus for the offshore industry. The cost is dependent on the availability described above. For the devices to perform smoothly, technological improvements are needed from to time apart from the maintenance [25]. The figure 8 [25] shows the key offshore wind operations and maintenance activity.

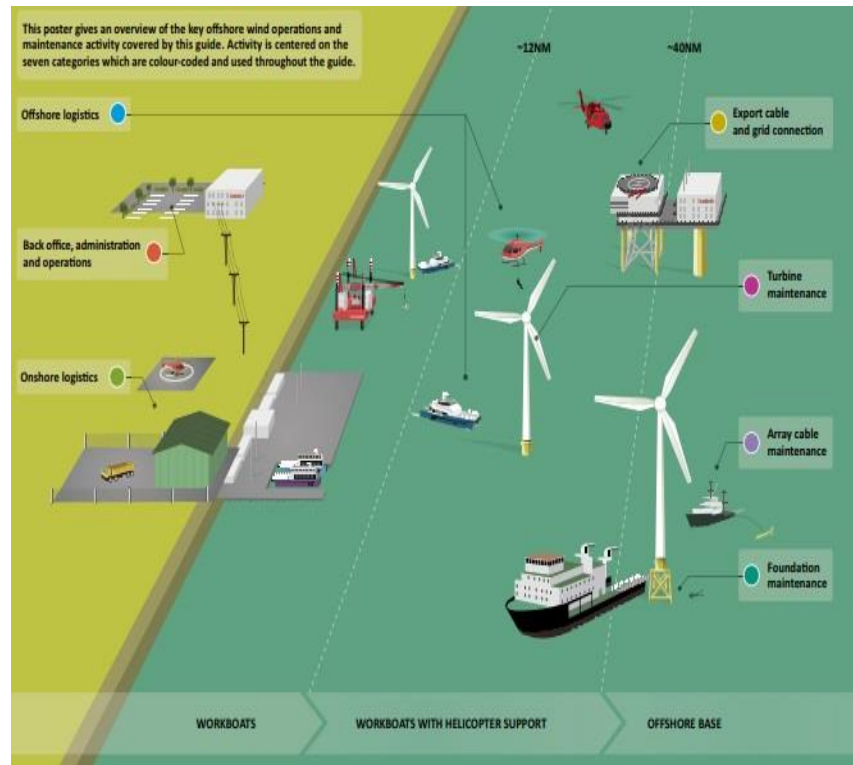

Fig. 8.Key offshore operation and maintenance activities [25]

\section{DECOMMISSIONING}

Decommissioning is an important aspect of end of life solution to an offshore wind farm. It has historically been given less attention by the developers due to the costs involved with it. The average lifespan of the windfarm is usually 20-25 years and a sustainable decommissioning planning report is to be prepared and submitted to the planning authority during project construction [26]. The decommissioning operation is dependent on the site-specific factors like distance from the shore, size of the windfarm and the prevalent weather conditions during the decommissioning. The expected decommissioning of offshore windfarms in EU is shown in figure 9 [27]. Thedecommissioning can be divided into three steps:

- The planning for the decommissioning where all the time and costs involved are estimated and an efficient sustainable solution is chalked out for the entire process.

- Hiring the necessary equipment and the process of removing the structures.

- Monitoring the site's recovery and proper disposal of the structure.

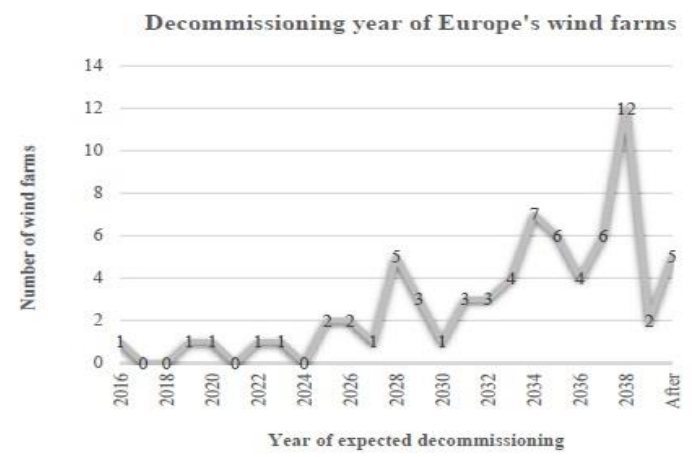

Fig. 9. Expected decommissioning of offshore windfarms in Europe [27]

The cost of the decommissioning is estimated to be $3 \%$ of the entire project cost. The estimation is made at the beginning of the project and hence may vary at the end of life of the project which maybe after 25 years. The developer should be smart enough to include the inflation, currency value over a period of 25 years to estimate the overall cost. It is also dependent on a number of factors such as the availability of the vessel and the weather. Figure 10 [28] shows the breakdown of costs for decommissioning. The majority of the costs are for offshore preparation and foundation removal. The disassembly of the heavy structures such as the foundations and turbines are about $19 \%$ of the total cost of decommissioning. The present figure for decommissioning is estimated to be around €200,000600,000/MW [28].

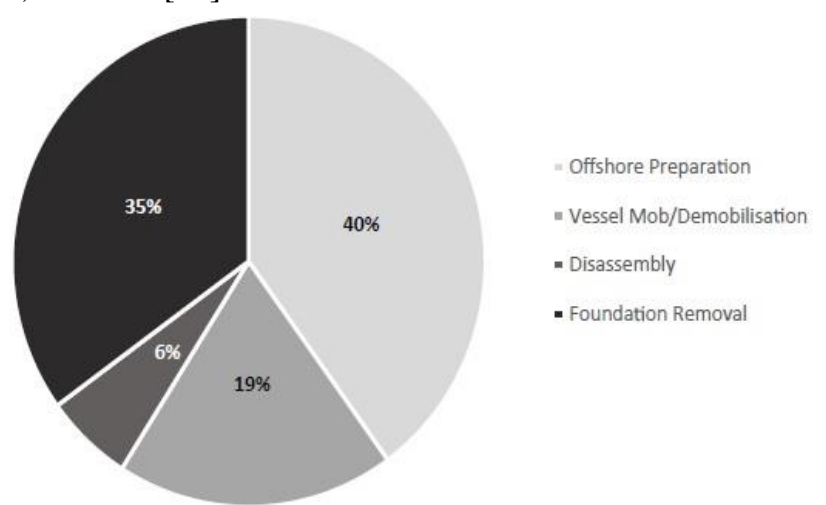

Fig. 10.Breakdown of costs [28]

\section{RESULTS \& ECONOMIC ASPECTS OF WINDFARM DEVELOPMENT}

Offshore windfarm development requires a lot of capital investment. The investment and returns from the project can be divided into different stages namely Capital Expenditure (CAPEX), Operational Expenditure (OPEX) and Levelized Cost of Energy (LCOE).

The capital expenditure includes the cost for the development and consenting of the project from relevant authorities. It also includes the cost of installation, commissioning and decommissioning. The capital costs are dependent on generating capacity,

Published By:

Blue Eyes Intelligence Engineering

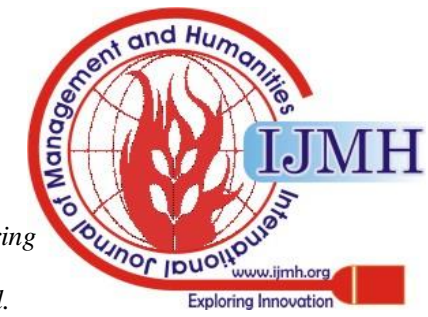


distance from the shore as the foundation, cable and installation costs increase. The CAPEX is estimated to be about $€$ 3-4 million/MW [29]. For turbines with capacity ranging from $1-12 \mathrm{MW}$, the foundation costs the foundation costs vary from $€ 317,000$ at $7 \mathrm{~m}$ depth to $€ 360,000$ at $16 \mathrm{~m}$. At deeper waters with $35 \mathrm{~m}$ depth the costs tend to rise to $€ 620,000$ for the similar size of turbine [30]. Figure 11 shows the percentage of CAPEX costs involved in different activities [31].

The Operational Expenditure (OPEX) are the costs associated with day-to-day operation of the windfarm. The major part of the cost is associated with Operation \& Maintenance (O\&M). Figure 12 shows the costs associated with OPEX [32]. The maintenance costs include all technical, logistic and administrative costs required to maintain the asset in perfect condition over its life cycle. The operations include payment of salaries to all the personnel, fuel for the transportation etc. The licensing fees is generally applied by a select group of countries for the usage of the seabed. The annual OPEX costs varies from 30 $90 € / \mathrm{MWh}$ [32]. For the project to break even and be profitable, the returns from selling the power generated has to be more than OPEX costs.

The Levelized Cost of Energy (LCOE) is the total economic assessment of the costs involved to build and operate a power plant over its lifetime divided by the total power generated over its lifetime. The LCOE estimation is done by the developer to check whether the project is a profitable venture or not [31].

Wind turbines are normally designed for 5 -10 MW of rated power, but they can be further upgraded to $20 \mathrm{MW}$ by scaling up the design. The increase in size of the turbines lead to potential increase in the costs. Figure 13 [33] shows the cost of energy for upscaled turbines. It can be seen from the figure that the upscaling doesn't lead to decrease in the cost of energy. The costs gained in the operation and maintenance expenditure and other cost components like installation are offset by the increase in cost of the rotor, blades and nacelle as the size and diameter increases for the large turbines thereby leading to rise in the cost [33].

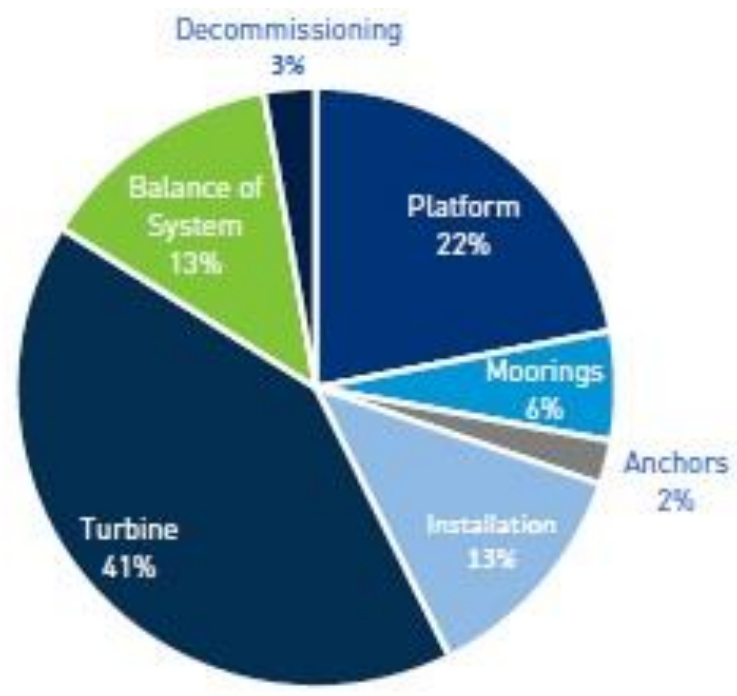

Fig. 11.Breakdown of costs for CAPEX [31]

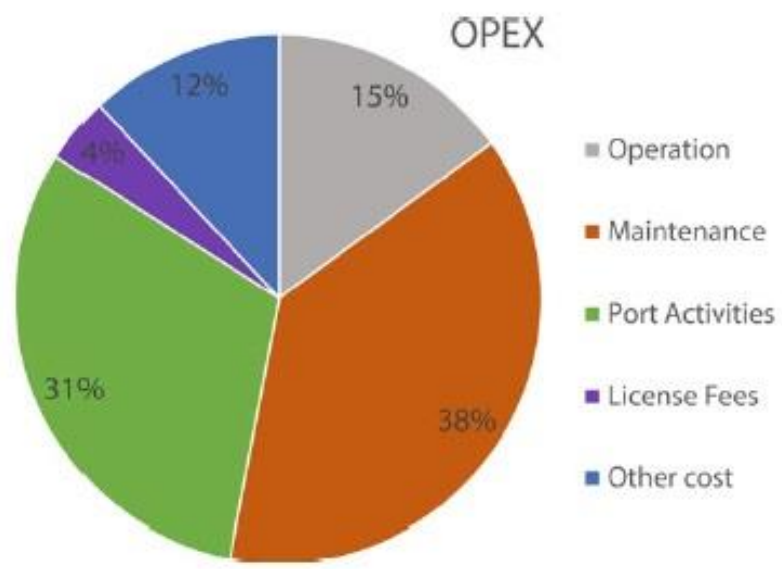

Fig. 12.Breakdown of costs for OPEX [32]

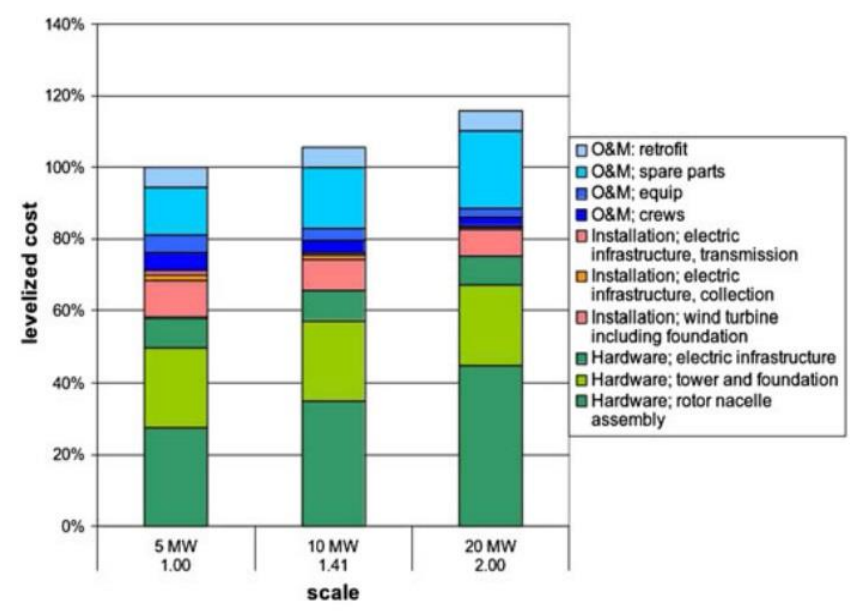

Fig. 13.Cost of energy for upscaled turbines [33]

\section{CONCLUSION AND DISCUSSION}

The development of offshore wind energy in Europe with the general consideration of design, logistics and cost is presented in this paper. Europe is one of the most energy intensive continent with heavy reliance on renewable energy. As discussed, wind energy is now the second largest form of energy in Europe with an installed capacity of $178.8 \mathrm{GW}$ (2018). The windfarm design and the economics related to the development of the windfarm should be planned and executed in a phased manner. The construction and installation of the wind turbines are critical aspect of the project as their timely execution will keep the costs from increasing.

With continuous funds being infused into the Research and Development (R\&D), a newer generation of turbines which are bigger and better like the GE Halide $\mathrm{X}$ with a capacity to generate $12 \mathrm{MW}$ at $63 \%$ capacity factor are coming to the market [34]. This is a great improvement over the present generation of turbines and will also be a stepping stone for the cost of wind energy being further reduced. While considering the generator types, SCIG is the most favoured type of generator in offshore installations due to its robustness and cost. There is further room for improvement in the performance of the wind turbine in-terms of usage of composite materials for the structure and blades, installation techniques and the transmission.

Published By:

Blue Eyes Intelligence Engineering

DOI:10.35940/ijmh.E0494.014520

Journal Website: www.ijmh.org

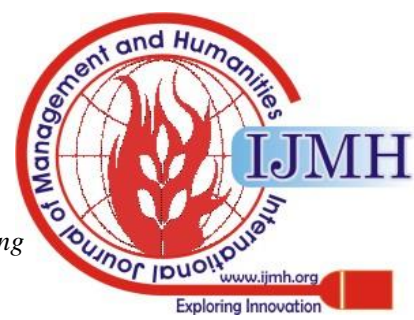

\& Sciences Publication

(C) Copyriaht: All rights reserved. 


\section{REFERENCES}

1. 'World Energy Resources', https://www.worldenergy.org/wpcontent/uploads/2016/10/WorldEnergy-Resources-Full-report-2016.10.03.pdf, accessed 22 April 2019

2. Mehmet Bilgili, Abdulkadir Yasar, 'Offshore wind power development in Europe and its comparison with onshore counterpart', Cukurova University, Turkey

3. Sahin AD,' Progress and recent trends in wind energy', Progress in Energy and Combustion Science ,2004,501-43.

4. 'Marine Management Organization: About Us', https://www.gov.uk/government/organisations/marine-managementorganisation/about, accessed 22 April 2019

5. Nikolaos N.:'Deep water offshore wind technologies', MSc Thesis, University of Strathclyde, 2004.

6. 6. 'European Wind Energy Association (EWEA) Offshore wind farms', http://www.ewea.org/, accessed 25 April 2019.

7. 'About wind statistics',https://windeurope.org/wpcontent/uploads/files/about-wind/statistics/WindEurope-AnnualStatistics-2017.pdf, accessed 25 April 2019

8. Sanjeev Malhotra. Dr. Ibrahim Al-Bahadly.:"Selection, Design and Construction of Offshore Wind Turbine Foundations', Wind Turbines, Intechopen, 2011

9. Malhotra Sanjeev, 'Selection, Design and Construction Guidelines for Offshore Wind Turbine Foundations', PB Research \& Innovation Report, 2007

10. Rodríguez Amenedo JL, Sainz Feito J., 'Tecnología De Aero generadores, In: Rueda F,editor. Sistem aseólicosdeproduccióndeenergíaeléctrica, Madrid: Rueda; 2003, p.99179.

11. Antonio Colmenar-Santos, Javier Perera-Perez, et al.,'Off shore wind energy:A review of the curren tstatus,challenges and future development in Spain', renewable and sustainable energy reviews 64, 2016, pp 1-18

12. López I,AndreuJ, et al.,'Review of wave energy technologies and the necessary power equipment', Renew Sustain Energy, Rev2013, 27:413-34

13. Delft University of Technology, 'Offshore Wind Energy: Ready to Power a Sustainable Europe, Concerted Action on Offshore Wind Energy in Europe', 2001

14. Hau E.,' Wind turbines: Fundamentals, technologies, application, economics',Springer Berlin, 2006,p.530

15. 'Wind technologies market report', https://www.energy.gov/sites/prod/files/2017/10/f37/2016_Wind_Tec hnologies_Market_Report_101317.pdf, accessed 28 April 2019

16. Esteban M.:' Propuesta de una metodología para la implantación de parques eólicos offshore', MSc thesis, Universidad Politécnica de Madrid, 2009.

17. 'Design of offshore wind turbine structures',http://www.dnv.com/press area/press releases/2011/newd esign practices offshore wind turbine structures.asp', accessed 29 April 2019.

18. Martinez-Luengo, M., Kolios, A., Wang, L.,'Structural health monitoring of offshore wind turbines: A reviewthrough the Statistical Pattern Recognition Paradigm', Renew. Sustain. Energy Rev.,2016, 64, 91-105.

19. Iris F.A.,VisUrsavas, 'Assessment approaches to logistics for offshore wind energy installation', Sustainable Energy Technologies and Assessments, Volume 14, April 2016, Pages 80-91

20. 'Offshore wind energy ready to power a sustainable Europe',http://www.offshorewindenergy.org/CAOWEE/downloads/C A-OWEE_Complete.pdf, accessed 20 April 2019

21. Bernd Scholz-Reiter, Michael Lütjen1, et al.,'Planning and control of logistics for offshore wind farms', 2013, University of Bremen, Germany

22. 'EWEA

Offshore 2009', http://www.ewea.org/fileadmin/files/library/publications/reports/Offs hore_Report 2009.pdf,accessed 1 May 2019,

23. Mark J. Kaiser, Brian F. Snyder,'Offshore Wind Energy Cost Modelling, Installation and Decommissioning', Springer, 2012

24. WorzykT, 'Submarine power cables: design, installation, repair, environmental aspects', Springer Berlin, 2009

25. 'A guide to UK offshore wind operations andmaintenance',http://www.hienergy.org.uk/Downloads/General\%2 0Documents/guide-to-uk-offshore-wind-operations-andmaintenance.pdf, accessed 2 May 2019

26. M.C. O'Hara, 'The legal and regulatory framework governing offshoredecommissioning', Constr. Law,2015
27. 27.'List of Offshore Wind Farms', http://www.lorc.dk/offshorewindfarms-map/list, accessed 2 May 2019

28. 'Decommissioning: Should they stay or should they go?' http://www.windpowermonthly.com/article/1349270/ decommissioning-stay-go, accessed 02 May 2019

29. MadariagaA,MartA, et al., 'Currentfactsabout offshorewindfarms', RenewableSustainableEnergyRev, 2012,16(5):3105-16 (06).

30. 'Greatexpectations:thecostofoffshorewindin UK watersunderstanding thepastandprojectingthefuture', UK Energy Research Centre, 2010.

31. 'Floating Offshore Wind: Market and Technology Review', Carbon Trust, June 2015

32. Lagerveld S., Röckmann C., \& Scholl M.,'A study on the combination of offshore windenergy with offshoreaquaculture', IMARES Report C056/14, accessed May 4, 2019

33. Kjeldsen, K.:'Cost reduction and stochastic modelling of uncertainties for wind turbine Design', MSc Thesis, Aarlborg University,2009

34. 'Halide X Offshore Wind Turbine Platform', https://www.ge.com/renewableenergy/wind-energy/offshorewind/haliade-X-offshore-turbine, accessed 04 May 2019

\section{AUTHOR PROFILE}

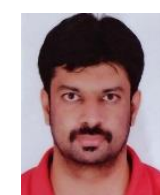

K R Prajwal, was born in 1991 in Karnataka, India. He has pursued BE in Electrical \& Electronics Engineering from Visvesvaraya Technological University, India. He also pursued MTech degree in Power Electronics from the same University, graduating in First Class in 2015. The author has an industry experience of 1 year in commissioning DCS and also has a teaching experience of 2 years. The author then went on to pursue his MSc in Marine Renewable Energy from University of Plymouth, UK in 2018 and graduating with a Merit degree. His research interests include wave energy devices, modelling of wave energy devices and offshore wind energy development.

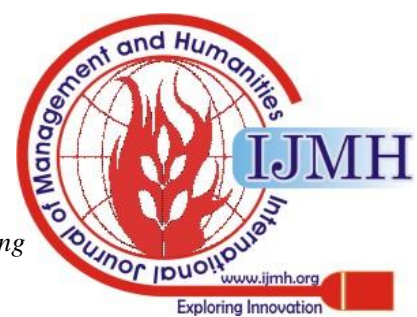

